\title{
Phosphorus-limited growth of the tropical seagrass Syringodium filiforme in carbonate sediments
}

\author{
F. T. Short ${ }^{1}$, W. C. Dennison ${ }^{2}$, D. G. Capone ${ }^{3}$ \\ ${ }^{1}$ Jackson Estuarine Laboratory, University of New Hampshire, RFD 2 Adams Point, Durham, New Hampshire 03824, USA \\ ${ }^{2}$ Center for Environmental and Estuarine Studies, University of Maryland, Horn Point Environmental Laboratories, \\ PO Box 775, Cambridge, Maryland 21613, USA \\ ${ }^{3}$ Center for Environmental and Estuarine Studies, University of Maryland, Chesapeake Biological Laboratory, PO Box 38, \\ Solomons, Maryland 20688, USA
}

\begin{abstract}
Seagrasses, along with all other marine primary producers, are generally considered to be nitrogen limited. Now experimental enrichments of the tropical seagrass Syringodium filiforme Kütz. show that phosphorus, rather than nitrogen, can be the primary limiting nutrient in a marine carbonate environment. Phosphorus enrichment of carbonate sediments resulted in dramatic increases in seagrass growth, biomass, and tissue phosphorus composition. Additionally, rhizosphere nitrogelı fixation increased in response to phosphorus enrichment, potentially making more nitrogen available to the plants.
\end{abstract}

\section{INTRODUCTION}

In the early 1970s, it was concluded that marine primary production is largely limited by the availability of nitrogen $(\mathrm{N})$ in the environment, and that phosphorus $(\mathrm{P})$ is sufficiently abundant not to be limiting (Ryther \& Dunstan 1971). Evidence for the general concept of $\mathrm{N}$ limitation has since been obtained in many marine ecosystems (Carpenter \& Capone 1981, Nixon 1981). The role of $P$ in marine carbonate environments has recently been re-examined, in part because of the realization that $\mathrm{N}$ is readily available in many tropical ecosystems through nitrogen fixation (Carpenter \& Capone 1981, Entsch et al. 1983, Smith 1984, Short et al. 1985, Powell et al. 1989). Smith \& Atkinson (1984) evaluated the extent of $N$ and $P$ limitation in determining net marine ecosystem production and presented evidence of $\mathrm{P}$ limitation at the ecosystem level. In contrast, we investigated the role of $\mathrm{P}$ and $\mathrm{N}$ in the primary production of a tropical seagrass (Syringodium filiforme Kütz.) using long-term ( $7 \mathrm{mo}) \mathrm{P}$ and $\mathrm{N}$ enrichment experiments. We obtained conclusive evidence that availability of $\mathrm{P}$ was the primary determinant of plant growth in this marine environment. Additionally, our results showed that rhizosphere $N_{2}$ fixation increased in direct proportion to $\mathrm{P}$ enrichment.
Seagrasses, rooted marine flowering plants, are abundant in carbonate sediments throughout the world's shallow tropical and subtropical oceans (Hartog 1970). Tropical seagrasses play an important role in processing and cycling nutrients in oligotrophic waters by maintaining high productivity through utilization of sediment nutrient resources (see review by Short 1987).

Nutrient cycling in marine carbonate sediments differs from that of marine terrigenous sediments (Rosenfeld 1979, Short 1987). Major regenerative processes of $\mathrm{N}$ are similar, although $\mathrm{N}$ fixation appears to be of greater significance in carbonate systems (Capone 1983). However, $P$ dynamics are very different due to the binding (which we refer to as sorption) of phosphate ions to the carbonate matrix (Bemer 1974. DeKanel \& Morse 1978, Gaudette \& Lyons 1980, Atkinson 1987). Organic $P$ in carbonate sediments, derived from seagrass tissue or deposition of other organic material on the sediment surface, is regenerated as dissolved phosphate and is rapidly removed by seagrass root uptake or sorption to carbonate grains (Short 1987). The apparent competition between plant and sediment for recycled $P$ stimulated our investigation of whether $\mathrm{P}$ or $\mathrm{N}$ limits seagrass growth in carbonate sediments. 


\section{METHODS}

A shallow-water ( 1 to $2 \mathrm{~m}$ ) semi-enclosed lagoon on the north end of San Salvador Island, Bahamas $\left(24^{\circ} 00^{\prime} \mathrm{N} ; 74^{\circ} 30^{\prime} \mathrm{W}\right)$ was selected to provide a carbonate sediment environment removed from continental influences. The study site had extensive monospecific stands of the tropical seagrass Syringodium filiforme with clear, oligotrophic, ocean water conditions (Short et al. 1985). Two research cruises on the RV 'Calanus' (Univ. Miami) provided the laboratory and field support facilities for our experimental manipulations designed to test nutrient limitation in the seagrass ecosystem. Our approach was to elevate the available P and $N$ in the sediments to various levels in order to stimulate plant response. Nutrients were increased relative to measured pore water concentrations, but excess amounts of $\mathrm{P}$ were added to overcome the binding of $\mathrm{P}$ to carbonate sediments. In July 1986, slowrelease fertilizer was added to seagrass sediments and in February 1987, plant response and nutrient dynamics assessed.

Experimental treatments consisted of triplicate plots of various additions of slow-release $\mathrm{N}$ and $\mathrm{P}$ fertilizer (donated by Osmocote, Sierra Chemical Co., CA, USA, $120 \mathrm{~d}$ release urea and phosphate) placed in the sediments below plugs of seagrass. The seagrass plugs were removed with a $0.02 \mathrm{~m}^{2}$ core sampler to a depth of 20 to $25 \mathrm{~cm}$. For the control plot, treatments $O N$ and $O P$, no fertilizer was placed below the seagrass plugs. The other $\mathrm{N}$ and $\mathrm{P}$ treatments in an incomplete factorial design reflect the multiple factors of $N$ and $P$ that were added to the sediment. The N-only treatments were $10 \mathrm{~N}$ and $100 \mathrm{~N}$, the P-only treatments were 50P, 200P and $2000 \mathrm{P}$, and the $\mathrm{N}+\mathrm{P}$ treatments were $10 \mathrm{~N}+200 \mathrm{P}$ and $100 \mathrm{~N}+2000 \mathrm{P}$. These levels were established in order to elevate pore water nutrients above ambient concentrations (ambient $\left[\mathrm{NH}_{4}^{+}\right]=100 \mu \mathrm{M}$ and ambient $\left.\left[\mathrm{PO}_{4}^{3-}\right]=2 \mu \mathrm{M}\right)$; thus, $50 \mathrm{P}$ gives a potential $\left[\mathrm{PO}_{4}^{3-}\right]=$ $100 \mu \mathrm{M}$. Note that this is the treatment level; for $\mathrm{N}$ treatments, most of the urea released into the pore water was converted to ammonium (Fenchel \& Blackburn 1979) and at least half of this ammonium was available to the plants immediately (Short et al. 1985): however, the actual pore water phosphate levels for the treatments were much lower because of carbonate sediment sorption. Actual pore water nutrient enrichment levels were estimated for different levels of $P$ addition by measuring the rate of sorption to carbonate sediments collected from the field site. Six replicate flasks containing $10 \mathrm{~g}$ of carbonate sediment were soaked in 0.21 of artificial seawater enriched at concentrations of $1.5,6.0$, and 60.0 uM phosphate. After $6 \mathrm{~h}$, the seawater was filtered and analyzed for change in phosphate concentration.
Seagrass biomass $\left(\mathrm{g} \mathrm{m}^{-2}\right)$ was measured on each of the triplicate treatments using $0.02 \mathrm{~m}^{2}$ cores. Seagrass tissue $C, N$ and $P$ content of dried $\left(24\right.$ h at $\left.80^{\circ} \mathrm{C}\right)$, powdered plant tissue was measured for $\mathrm{C}$ and $\mathrm{N}$ on $\mathrm{a}$ Carlo Erba C-N Analyzer; tissue P was measured by persulfate digestion (Menzel \& Corwin 1965). Seagrass growth $\left(\mathrm{g} \mathrm{C} \mathrm{m}^{-2} \mathrm{~d}^{-1}\right)$ was measured by tagging 10 rhizomes per treatment in July and collecting all newly grown leaf and rhizome material after 7 mo, counting leaf scars, multiplying by leaf weight and shoot density, and converting to $C_{1}$ P or $N$ values using tissue determinations. All seagrass data is presented as the mean of samples from the 3 replicate treatments, plus or minus $95 \%$ confidence interval ( $\bar{X} \pm 95 \% \mathrm{CI}$ ). Statistical data analysis was conducted on the incomplete factorial design using SAS Institute Inc. (1985) software on a VAX/VMS computer system.

Rates of $N$ fixation were measured in February 1987 by acetylene reduction on freshly collected sediments $(0$ to $5 \mathrm{~cm}$ ) using modified $30 \mathrm{cc}$ syringe cores. Six replicate samples for each site were incubated at ambient temperatures with $20 \%$ acetylene $(\mathrm{v} / \mathrm{v})$ and analyzed after short-term $(24 \mathrm{~h})$ incubations for both acetylene and ethylene by gas chromatography (Capone 1983). Daily fixation rates were based on a molar ratio $\mathrm{C}_{2} \mathrm{H}_{2}: \mathrm{N}_{2}$ of $2.6: 1$ and measured sediment density (Capone 1982).

\section{RESULTS}

Substantial increase in Syringodium filiforme leaf biomass was observed in the enriched areas after 7 mo of treatment with $\mathrm{P}$-only or $\mathrm{P}+\mathrm{N}$ fertilizer. Leaf biomass doubled with addition of P-only $(160 \pm 65 \mathrm{~g}$ dry wt $\left.\mathrm{m}^{-2}\right)$ and more than tripled with addition of both $\mathrm{P}$ and $\mathrm{N}\left(259 \pm 133 \mathrm{~g}\right.$ dry $\left.\mathrm{wt} \mathrm{m}^{-2}\right)$ compared to controls (82 \pm $74 \mathrm{~g}$ dry wt $\mathrm{m}^{-2}$ ), while $\mathrm{N}$ addition alone had no effect on leaf biomass.

Nutrients added to the carbonate sediments were not all available to the plants; aside from the small losses due to diffusion and microbial activity, a large amount of the added $P$ was lost to the sediments themselves. In laboratory experiments, the pore water nutrient levels that result from $\mathrm{P}$ addition to carbonate sediments were examined. These experiments show that $\mathrm{P}$ sorption is a linear function of the phosphate concentration established by $\mathrm{P}$ addition to the pore water (Fig. 1). The P available to the plants was reduced to ca $14 \%$ of the fertilizer-released $P$ (per day) as a result of $P$ sorption by the sediments

Nutrient enrichment with high levels of slow-release $P$ significantly increased seagrass growth (Table 1) to more than 4 times the control value, which was $1.7 \pm$ $0.5 \mathrm{~g} \mathrm{C} \mathrm{m}^{-2} \mathrm{~d}^{-1}$ (Fig. 2). P addition had a highly signifi- 


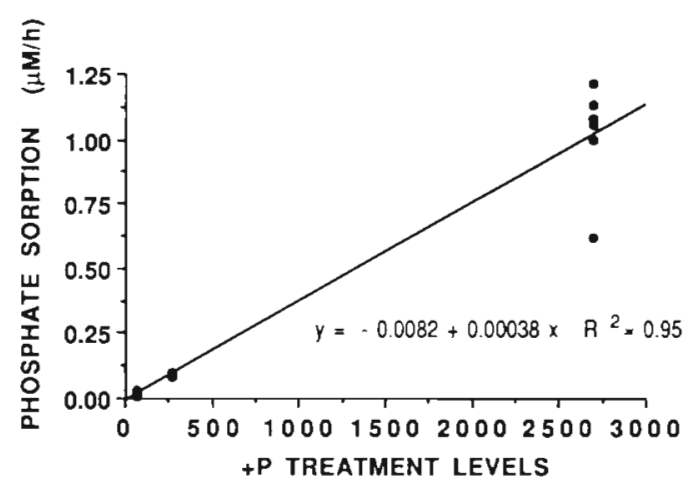

Fig. 1. Phosphate sorption by carbonate sediments collected from the experimental enrichment site at San Salvador Island, Bahamas. The sorption of $P$ to carbonate sediments from the experimental site was linearly correlated $\left(R^{2}=0.95\right)$ with the concentration of phosphate in the pore water and with the $+P$ treatment levels of the fertilization experiment. The constant sorption rate shows that daily about $86 \%$ of the $\mathrm{P}$ in the pore water is removed by the carbonate sediments

Table 1. Syringodium filiforme growth. Univariate (ANOVA) and multivariate (MANOVA) variance analysis for effects of $P$, $N$ and $N+P$ additions on seagrass growth expressed as rates of carbon (C), nitrogen (N), and phosphorus (P) incorporation into plant tissue. Effect of $\mathrm{P}$ addition is highly significant $(\mathrm{p}<0.01, \cdots)$ for all incorporation rates. Effect of $\mathrm{N}$ addition is highly significant $(p<0.01, \cdots)$ only for $N$ incorporation, but is also significant $\left(\mathrm{p}<0.05,{ }^{\circ}\right)$ for carbon incorporation

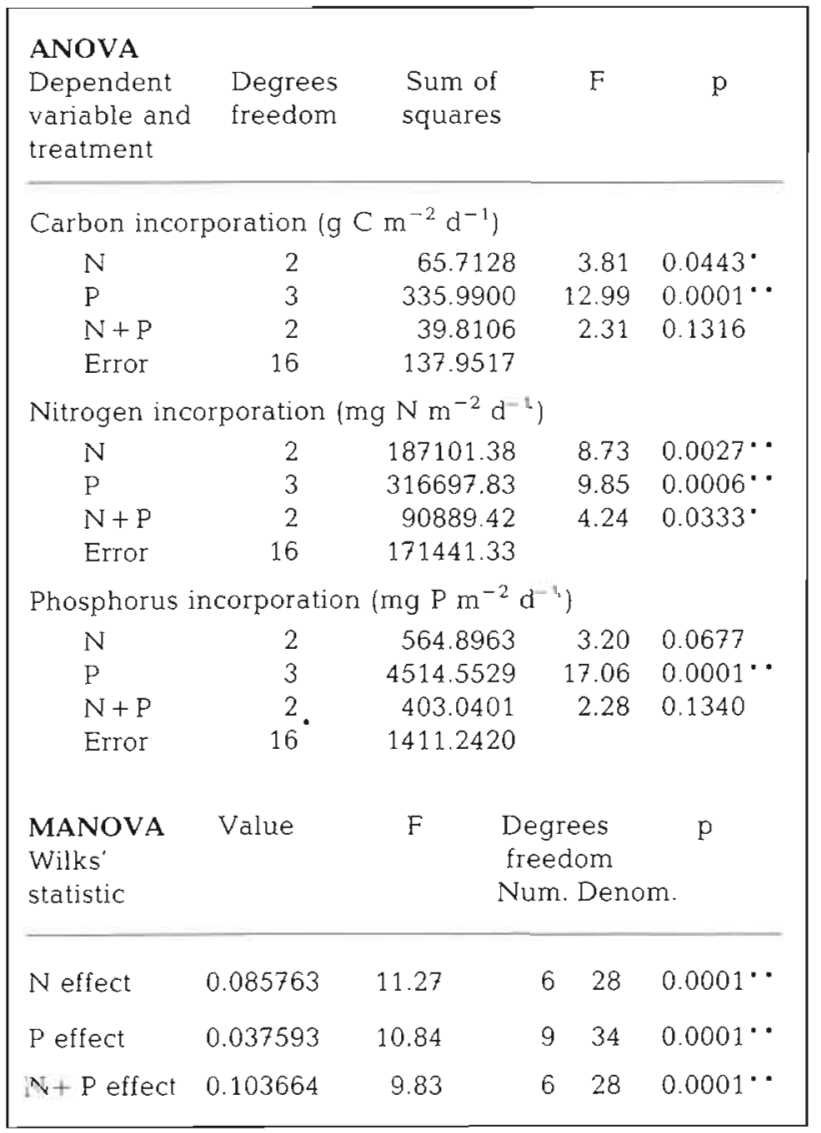

cant effect on the incorporation of $\mathrm{C}, \mathrm{N}$, and $\mathrm{P}$ into seagrass tissue (Table 1). However, the most significant effect of the increased levels of $\mathrm{P}$ was on the stimulation of $\mathrm{C}$ and $\mathrm{P}$ incorporation (Table 2).

Enrichment with slow-release $\mathrm{N}$ resulted in a highly statistically significant increase in $\mathrm{N}$ incorporation for plant growth, in a barely significant effect on the incorporation of $C$, but in no statistically significant effect on incorporation of $\mathrm{P}$ (Table 1). The effect of the increased $N$ treatments when further tested by a Duncan's multiple range test showed a significant difference only for the rate of $\mathrm{N}$ incorporation (Table 2). Additionally, 1way ANOVA on the $\mathrm{N}$-only treatments and the control for $\mathrm{C}$ incorporation showed no statistically significant effect of $\mathrm{N}$ addition (Fig. 2 ; df $=2, \mathrm{SS}=1.1943, \mathrm{~F}=$ $1.12, p=0.387$ ). Experimental additions of $P$ and $N$ together resulted in the highest growth rates, significantly greater than all other treatments except the $2000 \mathrm{P}$ level ( $\mathrm{p}<0.05$ for all least squares means comparisons; Fig. 2). The maximum growth rates for the 7 mo period were at the $100 \mathrm{~N}+2000 \mathrm{P}$ treatments, reaching $13.8 \mathrm{~g} \mathrm{C} \mathrm{m}^{-2} \mathrm{~d}^{-1}$, among the highest ever reported for any seagrass (McRoy \& McMillan 1977).

An additional significant response to nutrient fertilization was the large increase in seagrass tissue $\mathrm{P}$ content as seen in Table 2 under $P$ incorporation. Both the seagrass leaves $(0.06 \pm 0.01 \% \mathrm{P})$ and underground rhizome $(0.03 \pm 0.01 \% \mathrm{P})$ tissue $\mathrm{P}$ content increased with $\mathrm{P}$ addition, reaching a constant composition of $0.12 \pm 0.02 \% \mathrm{P}$.

The ratios of $\mathrm{N}$ to $\mathrm{P}$ were significantly affected by the addition of both the P-only and N-only treatments (Fig. 3; Table 3). N:P declined relative to the control for seagrass leaf tissue fertilized with P-only (Table 4), suggesting a shift from $\mathrm{P}$ limitation to $\mathrm{N}$ limitation (Nixon 1981). Fertilizer addition with N-only increased the $\mathrm{N}$ : $\mathrm{P}$ because of the increase in tissue $\mathrm{N}$ under $\mathrm{P}$ limited conditions (Table 4). However, when $N$ and $P$ were added together, the $\mathrm{N}: \mathrm{P}$ showed a slight decrease from the controls, also indicating some $\mathrm{N}$ limitation (Fig. 3).

Addition of $\mathrm{P}$, alone or in combination with $\mathrm{N}$, creates a shift from $\mathrm{P}$ limitation to an $\mathrm{N}$-limited condition. However, the substantial increases in seagrass production were evident only in the 2000P and N+P treatments (Fig. 2). Furthermore, treatments 2000P, $10 \mathrm{~N}+200 \mathrm{P}$, and $100 \mathrm{~N}+2000 \mathrm{P}$ always showed significantly greater growth than the other treatments ( $p$ $<0.05$ for all least squares means comparisons; Fig. 2). Thus, the low level $\mathrm{P}$ additions were not sufficiently available to the plants, due to carbonate sorption (Fig. 1), to substantially increase growth (Table 2) but did reduce $P$ limitation as evidenced by the decrease in N : P (Table 4).

At the control site, $30 \%$ of the $\mathrm{N}$ necessary for sea- 


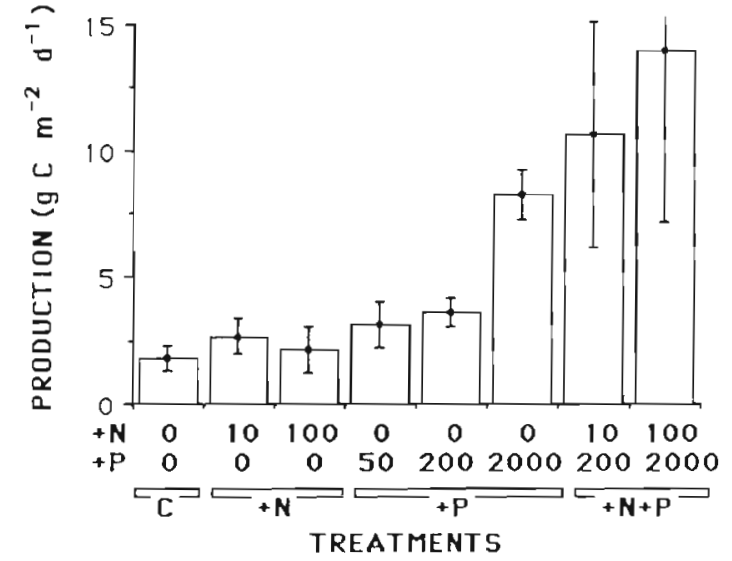

Fig. 2. Syringodium filiforme. Production rates, expressed as $\mathrm{C}$ incorporation, $( \pm 95 \% \mathrm{Cl}$ ) between July 1986 and February 1987 in an experimental enrichment at San Salvador Island, Bahamas. The $+\mathrm{N}=0$ and $+\mathrm{P}=0$ treatment represents the control plot where no fertilizer was placed below the seagrass plugs. The other $+\mathrm{N}$ and $+\mathrm{P}$ treatments reflect the multiple factors of $N$ and $P$ that were added to the sediment in order to elevate pore water nutrient levels above ambient concentrations (ambient $\left[\mathrm{NH}_{4}^{+}\right]=100 \mu \mathrm{M}$ and ambient $\left[\mathrm{PO}_{4}^{3-}\right]=$ $2 \mu \mathrm{M})$, e.g. $+\mathrm{P}=50$ gives $\left[\mathrm{PO}_{4}^{3-}\right]=100 \mu \mathrm{M}$. Note that this is the treatments level; the actual pore water nutrient levels of the treatments available to the plants were much lower due to $P$ sorption to carbonate sediments

Table 2. Duncan's multiple range test. Means within each treatment having the same grouping letter are not significantly different

\begin{tabular}{|c|c|c|c|c|}
\hline \multicolumn{2}{|c|}{$\begin{array}{l}\text { Treatment } \\
\text { and levels }\end{array}$} & $n$ & Grouping & Mean \\
\hline \multicolumn{5}{|c|}{ Carbon incorporation $\left(\mathrm{g} \mathrm{C} \mathrm{m}^{-2} \mathrm{~d}^{-1}\right)$} \\
\hline N & $\begin{array}{l}100 \\
10 \\
0\end{array}$ & $\begin{array}{r}6 \\
6 \\
12\end{array}$ & $\begin{array}{l}\text { A } \\
\text { A } \\
\text { A }\end{array}$ & $\begin{array}{l}8.050 \\
6.648 \\
4.192\end{array}$ \\
\hline$P$ & $\begin{array}{l}2000 \\
200 \\
50 \\
0\end{array}$ & $\begin{array}{l}6 \\
6 \\
3 \\
9\end{array}$ & $\begin{array}{l}\text { A } \\
\text { B } \\
\text { C } \\
\text { C }\end{array}$ & $\begin{array}{r}11.105 \\
7.122 \\
3.117 \\
2.198\end{array}$ \\
\hline \multicolumn{5}{|c|}{ Nitrogen incorporation ( $\mathrm{mg} \mathrm{N} \mathrm{m} \mathrm{m}^{-2} \mathrm{~d}^{-1}$ ) } \\
\hline $\mathrm{N}$ & $\begin{array}{l}100 \\
10 \\
0\end{array}$ & $\begin{array}{r}6 \\
6 \\
12\end{array}$ & $\begin{array}{l}\mathrm{A} \\
\mathrm{B} \\
\mathrm{B}\end{array}$ & $\begin{array}{r}313.8 \\
172.8 \\
97.6\end{array}$ \\
\hline $\mathrm{P}$ & $\begin{array}{l}2000 \\
200 \\
50 \\
0\end{array}$ & $\begin{array}{l}6 \\
6 \\
3 \\
9\end{array}$ & $\begin{array}{l}\mathrm{A} \\
\mathrm{B} \\
\mathrm{B} \\
\mathrm{B}\end{array}$ & $\begin{array}{r}363.2 \\
1.68 .5 \\
89.7 \\
70.2\end{array}$ \\
\hline \multicolumn{5}{|c|}{ Phosphorus incorporation ( $\mathrm{mg} \mathrm{P} \mathrm{m}^{-2} \mathrm{~d}^{-1}$ ) } \\
\hline N & $\begin{array}{l}100 \\
10 \\
0\end{array}$ & $\begin{array}{r}6 \\
6 \\
12\end{array}$ & $\begin{array}{l}\mathrm{A} \\
\mathrm{A} \\
\mathrm{A}\end{array}$ & $\begin{array}{l}24.70 \\
19.97 \\
13.23\end{array}$ \\
\hline $\mathrm{P}$ & $\begin{array}{l}2000 \\
200 \\
50 \\
0\end{array}$ & $\begin{array}{l}6 \\
6 \\
3 \\
9\end{array}$ & $\begin{array}{l}A \\
B \\
C \\
C\end{array}$ & $\begin{array}{r}37.45 \\
22.89 \\
7.86 \\
4.57\end{array}$ \\
\hline
\end{tabular}

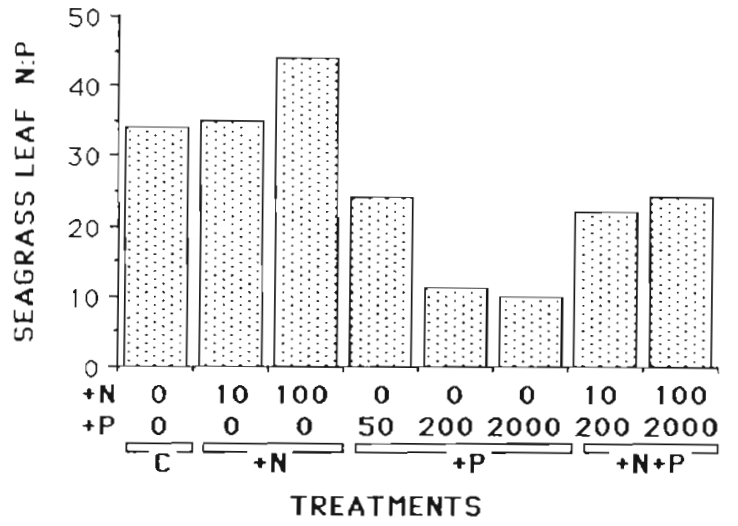

Fig. 3. Syringodium filiforme. N:P for leaf samples collected after 7 mo of $+\mathrm{N}$ and $+\mathrm{P}$ treatments as in Fig. 2

Table 3. Syringodium filiforme. Sediment nitrogen fixation rates and nitrogen to phosphorus ratios (N:P) for leaf tissue. Univariate (ANOVA) 2-way variance analysis for the effects of $P, N$ and $\mathrm{N}+\mathrm{P}$ additions (treatments) on $\mathrm{N}$-fixation and leaf $\mathrm{N}$ : $\mathrm{P}$. The effects of both $P$ and $N$ additions were significant $\left(p<0.05,{ }^{\circ}\right)$ for

$N$-fixation and highly significant $(p<0.01, \cdots)$ for $N: P$

\begin{tabular}{|lrrrc}
$\begin{array}{l}\text { Dependent } \\
\text { variable and } \\
\text { treatment }\end{array}$ & $\begin{array}{c}\text { Degrees } \\
\text { freedom }\end{array}$ & $\begin{array}{c}\text { Sum of } \\
\text { squares }\end{array}$ & $F$ & $p$ \\
\hline N-fixation $\left(\right.$ nmol g $^{-1} \mathrm{~h}^{-1}$ ) & & & \\
$\mathrm{N}$ & 2 & 123.5150 & 5.03 & $0.0113^{\circ}$ \\
$\mathrm{P}$ & 3 & 160.4464 & 4.06 & $0.0131^{\circ}$ \\
$\mathrm{N}+\mathrm{P}$ & 2 & 28.2147 & 1.07 & 0.3526 \\
Error & 40 & 527.3330 & & \\
$\mathrm{~N}$ : $\mathrm{P}$ (atomic ratio) & & & \\
$\mathrm{N}$ & 2 & 593.4128 & 35.73 & $0.0001^{\cdots}$ \\
$\mathrm{P}$ & 3 & 1531.3780 & 61.46 & $0.0001 \cdots$ \\
Error & 8 & 66.4402 & & \\
\hline
\end{tabular}

grass production could be accounted for by nitrogen fixation (Fig. 4). The fixation of $\mathrm{N}_{2}$, measured to be $14 \mathrm{mg} \mathrm{N} \mathrm{m} \mathrm{m}^{-2} \mathrm{~d}^{-1}$ at the control site, could represent a substantial input of new $N$ into the ecosystem. Fertilization with levels of $N$ did not affect growth (Table 2) but significantly inhibited $N$ fixation (Table 4), while P addition significantly stimulated the $N$ fixation rate (Table 3).

\section{DISCUSSION}

Phosphorus limitation in seagrass beds was eliminated by adding P-only to the sediments, and P enrichment levels resulted in both significantly increased growth (Table 2) and significantly increased rates of rhizosphere $\mathrm{N}$ fixation (Table 3). At the greatest $\mathrm{P}$ 
Table 4. Duncan's multiple range test. Means within each treatment having the same grouping letter are not significantly different

\begin{tabular}{|c|c|c|c|c|}
\hline \multicolumn{2}{|c|}{$\begin{array}{l}\text { Treatment } \\
\text { and levels }\end{array}$} & $\mathrm{n}$ & Grouping & Mean \\
\hline \multicolumn{5}{|c|}{ N-fixation (nmol $g^{-1} h^{-1}$ ) } \\
\hline N & $\begin{array}{l}100 \\
10 \\
0\end{array}$ & $\begin{array}{l}12 \\
12 \\
24\end{array}$ & $\begin{array}{l}A \\
A B \\
B\end{array}$ & $\begin{array}{l}1.036 \\
2.640 \\
4.961\end{array}$ \\
\hline $\mathrm{P}$ & $\begin{array}{l}2000 \\
200 \\
50 \\
0\end{array}$ & $\begin{array}{r}12 \\
12 \\
6 \\
18\end{array}$ & $\begin{array}{l}A B \\
A \\
B \\
B\end{array}$ & $\begin{array}{l}4.762 \\
5.639 \\
1.708 \\
1.562\end{array}$ \\
\hline \multicolumn{5}{|c|}{$N: P$ (atomic ratio) } \\
\hline N & $\begin{array}{l}100 \\
10 \\
0\end{array}$ & $\begin{array}{l}4 \\
4 \\
8\end{array}$ & ${ }^{\mathrm{A}} \mathrm{B}$ & $\begin{array}{l}33.78 \\
29.02 \\
19.69\end{array}$ \\
\hline $\mathrm{P}$ & $\begin{array}{l}2000 \\
200 \\
50 \\
0\end{array}$ & $\begin{array}{l}4 \\
4 \\
2 \\
6\end{array}$ & $\begin{array}{l}\mathrm{A} \\
\mathrm{A} \\
{ }_{\mathrm{B}} \\
\mathrm{C}\end{array}$ & $\begin{array}{l}16.81 \\
16.62 \\
24.03 \\
37.82\end{array}$ \\
\hline
\end{tabular}

enrichment, where growth was 3 times the control, N fixation also increased about 3-fold (Fig. 4).

Enrichments of $\mathrm{P}$ and $\mathrm{N}$ together resulted in a 3 -fold increase in biomass, with a concomitant decrease in $\mathrm{N}$ fixation due to inhibition by added $N$. This combined $P$ and $\mathrm{N}$ enrichment reduced both $\mathrm{P}$ and $\mathrm{N}$ limitation and stimulated very high growth rates at a constant $\mathrm{N}: \mathrm{P}$.

Our experiments clearly demonstrate that $P$ is the primary factor limiting the growth of the seagrass Syringodium filiforme in this tropical carbonate

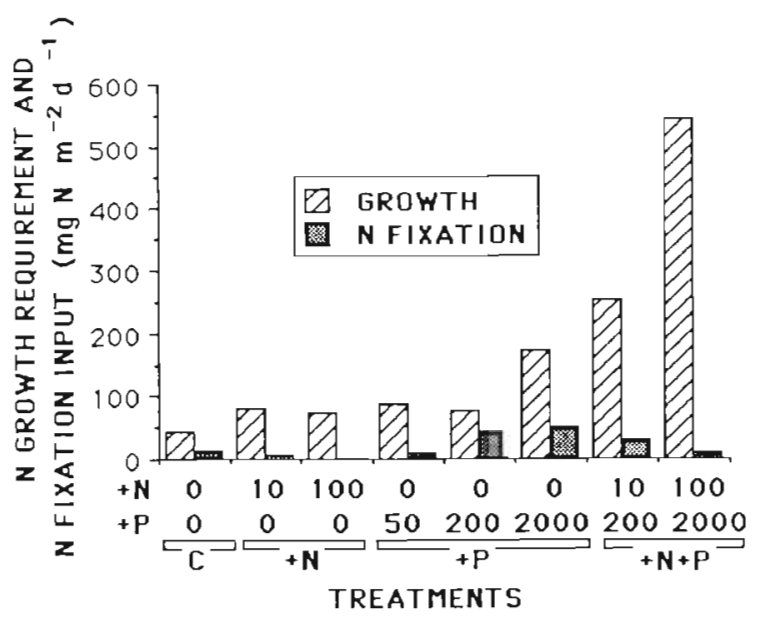

Fig. 4. Comparison of plant $N$ growth requirement and rhizosphere $\mathrm{N}$ fixation at each level of treatment. Seagrass $\mathrm{N}$ incorporation as $\mathrm{mg} \mathrm{N} \mathrm{m} \mathrm{m}^{-2} \mathrm{~d}^{-1}$ was calculated from the carbon production data (Fig 2) and the C:N determinations for each treatment environment. The substantial increase in seagrass growth, biomass, and tissue $\mathrm{P}$ content after $\mathrm{P}$ addition shows alleviation of $\mathrm{P}$ limitation and implies a shift to $\mathrm{N}$ limitation. However, severe $\mathrm{N}$ limitation is mitigated by the increased $N$ fixation associated with greater seagrass growth following the addition of $P$. While $\mathrm{N}$ addition alone had no effect on seagrass growth, $\mathrm{P}$ and $\mathrm{N}$ added together further stimulated seagrass growth by reducing both $\mathrm{P}$ and $\mathrm{N}$ limitation. Thus, we show that in unenriched carbonate sediment environments seagrass growth is P limited, and significant amounts of $\mathrm{N}$ may be supplied by fixation in the sediments.

Acknowledgements. Financial support was provided by National Science Foundation grant OCE-8515639. We acknowledge the assistance of $M$. E. Hines, J. M. O'Neil, E. C. Brainard, S. Dunham, D. Parrish, M. F. Bautista, R. E. Grizzle, C. A. Short, D. T Gerace (CCFL Bahamian Field Station), B. Storr, and Captain W. L. Newton and the crew of the RV 'Calanus', Jackson Estuarine Laboratory contribution no. 210.

\section{LITERATURE CITED}

Atkinson, M. J. (1987). Low phosphorus sediments in a hypersaline marine bay. Estuar coast. Shelf Sci. 24: 335-347

Berner, R. A. (1974). Kinetic models for early diagenesis of nitrogen, sulfur, phosphorus, and silicon in anoxic marine sediments. In: Goldberg, E. D. (ed.) The sea, Vol. 5. John Wiley and Sons, New York, p. 427-450

Capone, D. G. (1982). Nitrogen fixation (acetylene reduction) by rhizosphere sediments of the eelgrass Zostera marina. Mar. Ecol. Prog. Ser. 10:67-75

Capone, D. G. (1983). $\mathrm{N}_{2}$ fixation in seagrass communities. Mar. Tech. Soc. J. 17: 32-37

Carpenter, E. J., Capone, D. G. (eds.) (1981). Nitrogen in the marine environment. Academic Press, New York

DeKanel, J., Morse, J. W. (1978). The chemistry of orthophosphate uptake from seawater onto calcite and aragonite. Geochim. Cosmochim. Acta 42: 1335-1340

Entsch, B., Boto, K. G., Sim, R. G., Wellington, J. T. (1983). Phosphorus and nitrogen in coral reef sediments. Limnol. Oceanogr. 28: 465-476

Fenchel, T., Blackburn, T. H. (1979). Bacteria and mineral cycling. Academic Press, New York

Gaudette, H. E., Lyons, W. B. (1980). Phosphate geochemistry in nearshore carbonate sediments: suggestion of apatite formation. Soc. Econ. Paleon. Min. Spec. Publ. 29: 215-225

Hartog, C. Den (1970). The seagrasses of the World. North Holland Publ. Co., Amsterdam

McRoy, C. P., McMillan, C. (1977). Production ecology and physiology of seagrass. In: McRoy, C. P., Helfferich, C. (eds.) Seagrass ecosystems. Marcel Dekker, Inc., New York, p. 53-87

Menzel, P. W., Corwin, N. (1965). The measurement of total phosphorus in seawater based on the liberation of organically bound fraction by persulfate oxidation. Limnol. Oceanogr. 10: 280-282

Nixon, S. W. (1981). Remineralization and nutrient cycling in coastal marine ecosystems. In: Neilson, B. J., Cronin, L. E. 
(eds.) Estuaries and nutrients. Humana Press, Clifton, NJ, p. $111-138$

Powell, G. V N., Kenworthy, W. J., Fourqurean, J. F. (1989) Experimental evidence for nutrient limitation of seagrass growth in a tropical estuary with restricted circulation Bull. mar Sci. 44: 324-340

Rosenfeld, J. K. (1979). Ammonium adsorption in nearshore anoxic sediments. Limnol. Oceanogr. 24: 356-364

Ryther, J. H., Dunstan, W. N. (1971). Nitrogen, phosphorus and eutrophication in the coastal marine environment. Science 171: 1008-1013

SAS Institute Inc. (1985). SAS ${ }^{\otimes}$ user's guide: statistics, Version 5 Edn. SAS Institute Inc., Cary, NC

This article was submitted to the editor
Short, F. T (1987). Effects of sediment nutrients on seagrasses: literature review and mesocosm experiment. Aquat. Bot. 27: 41-57

Short, F. T., Davis, M. W. Gibson, R. A., Zimmermann, C. F. (1985). Evidence for phosphorus limitation in carbonate sediments of the seagrass Syringodium filiforme. Estuar coast. Shelf Sci. 20: 419-430

Smith, S. V. (1984). Phosphorus versus nitrogen limitation in the marine environment. Limnol. Oceanogr. 29: $1149-1160$

Smith, S. V., Atkinson, M. J. (1984). Phosphorus limitation of net production in a confined aquatic ecosystem. Nature. Lond. 307: 626-627

Manuscript first received: May 17, 1988

Revised version accepted: January 9, 1990 